DE ECONOMIST 158, NO. 2, 2010

\title{
WHAT DOES BEHAVIORAL ECONOMICS MEAN FOR POLICY? CHALLENGES TO SAVINGS AND HEALTH POLICIES IN THE NETHERLANDS
}

\author{
BY \\ PETER KOOREMAN*, HENRIËTTE PRAST**,***
}

\begin{abstract}
Summary
Key findings in behavioral economics are that people's behavior (revealed preferences) is often not in line with their intentions (normative preferences), that they are sensitive to the way choices are presented to them, and that their cognitive abilities are limited. This is manifest in particular in areas of intertemporal choice, like personal finance and health-related behavior. Policy makers can develop policies that help citizens to make choices that are more in line with their normative preferences. In this paper we summarize the behavioral evidence, discuss the motivations for interventions, and show how recent behavioral insights can help to improve upon existing policies. These new policies could be described as libertarian paternalism, and include setting defaults thoughtfully and using unorthodox commitment mechanisms.
\end{abstract}

Key words: behavioral economics, health policies, savings policies

JEL Code(s): D03, D14, I18

\section{INTRODUCTION}

God must love those common folk that behavioral science economists write about, because She made so many of them (Paul A. Samuelson 2006).

Policymakers intervene in market economies for a variety of reasons, using different types of policy instruments. These policies are motivated either by externalities and/or are based on paternalistic considerations: people may need help to avoid choices that they will regret at a later stage. Paternalistic regulation traditionally aims to protect people that are thought to be less capable to make decisions that are in their best interest: Children, because they like to play rather than do their homework; adolescents who may easily succumb

\footnotetext{
*Corresponding author: Department of Economics, Tilburg University, Tilburg, The Netherlands, e-mail: p.kooreman@uvt.nl

** Scientific Council for Government Policy, The Hague, The Netherlands.

*** Department of Finance, Tilburg University, Tilburg, The Netherlands
} 
alcohol; desperate adults in financial distress who may agree to an abusive contract - hence usury laws and health and safety regulations of dangerous occupations. ${ }^{1}$

Recent research in behavioral economics, however, shows that sizeable decision-making errors are not limited to vulnerable groups, but omnipresent and systematic. To mention one example, Choi et al. (2005) show that employees forgo thousands of dollars annually by not fully exploiting their employer match in a retirement savings plan. The revenues forgone are too large to be plausibly explained by transaction costs. Educational interventions often have little effect, and do not pass basic costs-benefit tests. Moreover, seemingly unimportant aspects of a choice setting - framing and defaults - often have large effects on behavior.

Findings like these have far-reaching implications for policy makers. First, they may expand the scope of paternalistic regulation beyond groups traditionally considered to be vulnerable. Second, they question the effectiveness of policies that rely on information and education. Third, since framing and defaults cannot be avoided, it is better to use them wisely. At the same time, behavioral economics findings provide policy makers with a new tool kit for policy design: If individual choice is affected by the choice architecture, governments can deliberately choose the architecture to achieve policy goals. Policies that do not recognize these (psychological) mechanisms may have counterproductive effects.

In this paper we first summarize the key insights from behavioral economics, in Section 2. Next, we discuss the motivations for interventions, focusing on the distinction between normative and revealed preferences in Section 3. In the light of the behavioral insights, we then rethink policy design in the Netherlands in the fields of personal finance (Section 4) and health-related behavior (Section 5). These are areas in which there is a large amount of evidence on systematic deviations from rationality. In both domains choices often have a large, long-term, and irreversible impact, both at an individual level and for society as a whole.

We conclude that current reason-based policies aimed at influencing individual choice are often inadequate in helping people make better choices. At the same time, many of these policies can be easily adapted to make them (much) more effective, often at very low costs.

\section{KEY FINDINGS IN BEHAVIORAL ECONOMICS}

Rational individual choice requires that decision makers have complete information, unlimited cognitive abilities, consistent preferences, and will-power.

1 Until 1956 married women in the Netherlands were thought of as another category incapable of contracting for themselves. In that year the law changed with the so-called "Lex-vanOven" law, named after the social democrat minister who took the initiative for the change. 
Both real-world and experimental evidence indicates that these conditions are rarely satisfied. This section summarizes the evidence. We do not intend provide a comprehensive review; several excellent recent surveys have been published; see for example DellaVigna (2009) and Camerer (2006).

\subsection{Incomplete Information, Limited Cognitive Abilities, and Choice Paralysis}

Stigler (1961) noted already half a century ago that information is a traded good, and that consumers are not necessarily perfectly informed in equilibrium. The raison d'être of many firms in the service sector is that they offer information and decision tools that may help clients with their choices: advertisements, brochures, internet tools, consultancies, product packaging, and specialized media.

Likewise, the concept of bounded rationality has been around for more than half a century; see Simon (1957). However, more precise evidence on the nature of bounded rationality is of relatively recent date. In particular, bounded rationality in the financial domain has been studied extensively. Studies for the US by Bernheim (1998) and Hogarth et al. (2003) reveal that most respondents do not understand basic financial concepts like simple interest calculations, let alone more complex ones related to bonds, stocks and mutual funds. Note that these findings apply to a country that is traditionally committed to self-reliance and individual responsibility. These authors also find that people often fail to understand loans and, particularly, mortgages? a finding that is confirmed by Miles (2005) for UK borrowers. Lusardi and Mitchell (2005) surveyed Americans of the age 50+ and conclude that only half of these respondents could correctly answer two simple questions regarding interest and inflation. van Rooij et al. (2007) find that 50 percent of Dutch employees consider themselves to be financially very incompetent, while a minority of only 20 percent regarded themselves as knowledgeable. In a survey only 40 percent of respondents provided correct answers to five very simple questions on basic knowledge regarding inflation and interest. Scores on investment questions were also poor, with four out of five respondents missing at least two questions.

Economists have traditionally assumed that more choice is better. This view is now challenged, as several studies indicate that when there is "too much" choice, people are discouraged from choosing anything. Iyengar and Lepper (2000) found that if consumers can choose between 26 types of jam, 60 percent will take part in tasting, compared with 40 percent if only six types are offered. But, while in the 6-options group 30 percent actually decide to buy, only 3 percent in the 26-options group decide to buy. If this "choice paralysis" already applies to products that do not require much expert knowledge like jam, it is not difficult to imagine the role it plays in the choice between complicated products, such as financial ones; see also Schwartz (2005). 


\subsection{Default Effects}

Evidence shows that people often "choose not to choose". As a result, defaults or standards (what you choose if you do not take action, silent consent) may strongly affect behavior. The default effect exists for a wide range of domains. Evidence includes car insurance plan choices (Johnson et al. 1993), organ donation decisions (Johnson and Goldstein 2003; Abadie and Gay 2006), and pizza consumption (Levin et al. 2002), and it is especially prominent in retirement saving. Defaults play a role in pension plan participation, in the retirement savings rate, in pension portfolio choice and in the withdrawal of pension wealth. In a study by Beshears et al. (2006), over 90 percent of employees immediately participates in a pension plan in the case of automatic enrollment. If instead the default is non-enrollment, employees hesitate to enroll. This is illustrated by Figure 1, taken from Beshears et al. (2006). Company A changed its enrollment policy for new employees, from automatic non-enrollment (opt-in) to automatic enrollment (opt-out). As Figure 1 shows, with automatic non-enrollment participation starts below 60 percent of employees and increases to about 80 percent in two years. With automatic enrollment, participation is almost 100 percent within three months.

Figure 1 also illustrates the powerful effect of the default savings rate. Company A doubled its default savings rate for new hires, from 3 to 6 percent. As Figure 1 shows, participation was the same under the 3 and the 6 percent default rate.

The effect of default savings rates on retirement savings is not unambiguous, however. Whereas more employees do participate in case of automatic enrollment, there may be employees who would have chosen a higher savings rate than the default if no automatic enrollment and rate had been offered. This is shown in the authors' Figure 2, which compares the distribution of the

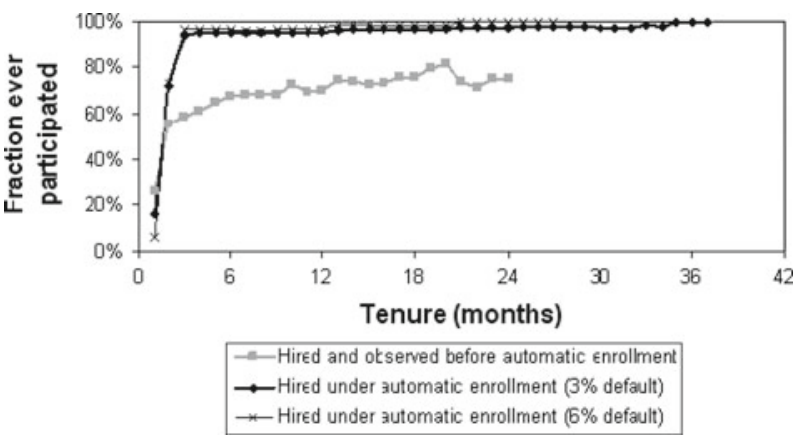

Figure 1 - Automatic enrollment for new hires and savings plan participation: company A. Source: Beshears et al. (2006) 


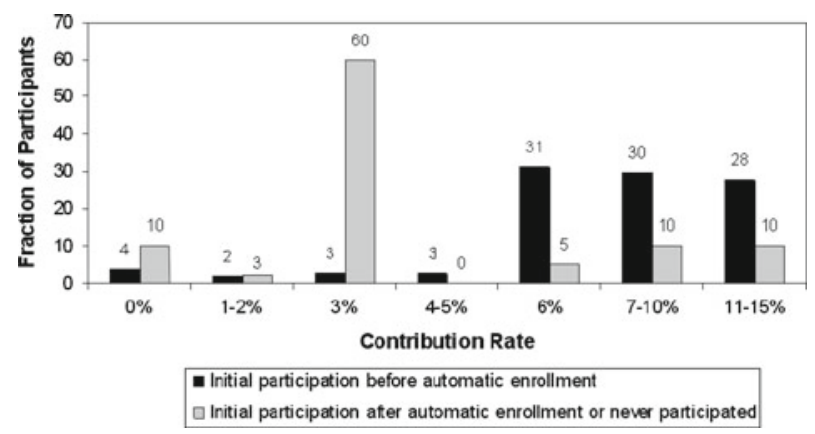

Figure 2 - Automatic enrollment for existing hires and the distribution of 401(k) contribution rates: Company A(25-48 months tenure). Source: Beshears et al. (2006)

retirement savings rate in Company A before and after default enrollment was introduced. The picture shows that the savings rate before automatic enrollment was 6 percent or higher for about 90 percent of the plan participants. After automatic enrollment was introduced, 60 percent of participants chose the default rate of 3 percent, and only 25 percent of new participants saved 6 percent or more. Thus, where automatic enrollment speeds up participation and increases the participation rate, it does not necessarily increase total retirement savings.

Default effects in retirement saving are not limited to participation and to the contribution rate. The asset allocation of the retirement savings portfolio is also default-sensitive (Beshears et al. 2006; Cronquist and Thaler 2004; Choi et al. 2005). Between one-third and 50 percent of employees hold some of their balances in the default portfolio offered by the employer, and between 25 and 40 percent hold all their balances in this fund.

With regard to health, the dominant culture in most societies is to avoid doctors unless some immediate health problem emerges. The attitudes of healthcare providers and citizens can be characterized as disease management rather than health management. Strong evidence suggests, however, that preventive healthcare is underutilized; See, for example, Weinstein (2005). This implies that welfare may be increased by changing the default of not-going to a doctor to going to a doctor on a regular basis for screening and other preventive interventions. Another area in health in which defaults play an important role is organ donation. See Section 5 for an elaboration.

\subsection{Framing Effects}

Another type of bias in decision making is people's sensitivity to the framing, or formulation, of the decision problem. There are several types of framing effects relevant in the context of life cycle saving and investing and/or health: 
- A long-standing literature has discussed money illusion, i.e. the phenomenon that people's preferences and behavior depend on irrelevant currency units. The currency unit in which a decision problem is expressed is obviously part of its framing. Using a variety of empirical approaches, researchers have found strong indications of money illusion. Examples are Shafir et al. (1997) using stated preference data, Fehr and Tyran (2001) using laboratory experiments, and Kooreman et al. (2004) using a quasiexperimental approach. Kooreman et al. (2004) found that after the introduction of the euro people donated more in real terms to a charity than they did before.

- If a choice is framed in terms of gains, people avoid risk. If it instead is framed in terms of losses, they choose risk? hoping to avoid losses. This effect displays an asymmetric risk appetite: people are risk-averse in the domain of winning, but risk-seeking in the domain of losing (Kahneman and Tversky 1984; see also Bernstein 1996). The risk-seeking behavior in the domain of losses runs counter to the standard assumption in prebehavioral microeconomic theory.

- People prefer choice in the (literal) middle. Benartzi and Thaler (2001) asked respondents to rate the attractiveness of portfolios that varied in terms of risk and return due to different percentages allocated to equities. They found that participants in defined-contribution schemes tended to avoid extremes, either by choosing the middle portfolio when offered three, or by allocating their savings equally over all of the portfolios they were offered. Moreover, respondents were inconsistent in the sense that when asked to rate portfolios, many preferred the median portfolio to their own. van Rooij et al. (2007) found similar results for employees in the Netherlands.

- Framing effects also occur in the domain of probability and risk perceptions. Evidence includes insurance and health prevention. Johnson et al. (1993) reported the results of an experiment with three groups of individuals who had to decide how much they would pay for a flight insurance policy that would provide life insurance of 100,000 dollar in case they should die during a flight to London. Each group was offered different conditions for the coverage: death on the airplane due to any act of terrorism, due to any mechanical failure, or due to any reason. Whatever the risk attitudes of the participants, it would be rational if the mean Premium offered would be highest for the insurance policy that covers in case of death due to any reason. Instead, the premiums that the groups were willing to pay did not differ. Persuasive effects of framing can also be found in health campaigns. Campaigns stressing reductions in mortality (e.g. from 6 to 4 percent) are more effective than campaigns stressing increases in survival (e.g. from 94 to 96 percent). Presenting absolute risks is more effective than informing about relative risks, and presenting 
the positive effects of a breast-screening decision over the woman's lifetime is more effective than presenting the health effects in the next few years.

A specific example of framing is labeling (or "mental accounting"). Kooreman (2000) found that the marginal propensity to consume child clothing out of child benefit is ten times as large as the marginal propensity to consume child clothing out of other income. His result indicates that expenditures patterns can be influenced by merely changing the label of income components.

As a final example of the persuasive power of framing effects, consider the dilemma of combating disease (Bernstein 1996). Assume that a Minister of Healthcare needs to take a decision on how to fight a rare and highly contagious disease, which if no precautions are taken is expected to kill 600 people. $\mathrm{He}$ is presented with the following choice:

There are two ways of combating this disease. If we choose approach A, 200 lives out of the 600 will be saved. Method B offers a one-third chance that all 600 will be saved and a two-third chance that no-one will survive. Which method would you prefer?

In terms of human lives both methods offer the same expected outcomes: A has 200 lives saved at a probability of one. The only difference between A and B is that A offers certainty while B presents risk: one doesn't know how many people will be saved. Experimental evidence indicates that over seventy per cent of the people go for certainty and pick A.

However, the decision problem facing the Minister could also be formulated as follows.

There are two ways of combating this disease. If we choose approach $A$, 400 out of 600 people will die. Method B offers a one-third chance that no-one dies and a two-third chance that all will die. Which method would you prefer?

When framed this way, more than 70 percent choose method $\mathrm{B}$. The only difference between the decision problems is their wording. The first is presented in terms of gains (lives saved), the second in terms of loss (people dying).

\subsection{Lack of Willpower}

One special case of preference inconsistency involves the time dimension of preferences. Since Samuelson (1937), the conventional assumption in microeconomic theory has been that when choosing between current and future 
consumption the individual applies exponential discounting. However, as Samuelson himself stated, this assumption of time-consistent preferences is 'completely arbitrary'. Yet, exponential discounting, which implies that the ratio between consumption preferences in two periods is independent of time, has been the key assumption in microeconomic models. Empirical evidence, however, shows that humans typically make short-term choices that can harm their welfare across their planning horizon. Laibson (1997) points at the existence of self-enforcement mechanisms like Christmas Clubs as an indication of will-power problems. ${ }^{2}$ The problem of self-control is formally described by assuming that people discount future utility hyperbolically, which implies that discounting is not constant, but a decreasing function of time. As a result, in the present it looks easy to start saving (dieting, quit smoking) at some point in the future. But by the time the future has become the present, it will be as difficult as it is today. This implies an incentive for consumers to constrain their own future choices, provided they are sophisticated, that is that they are aware of their preference inconsistency. ${ }^{3}$

Evidence of lack of willpower is also found in the health domain. DellaVigna and Malmendier (2006) found that members of a health club who chose a flat monthly fee contract of $\$ 70$ paid 70 percent more than if they would have chosen to pay per visit. They also found that people delay canceling their subscription, possibly due to overconfidence about future attendance. Other indications of a lack of willpower are the large amounts of money spent on dietary and smoking-cessation programs. In the Netherlands, only 14 percent of smokers are satisfied with their habit, and do not consider stopping. One quarter of smokers would like to stop within a year, while 14 percents would like to stop, but not within a year (another indication of procrastination). Forty percent of the Dutch population is currently overweight (BMI between 25 and 30), 10 percent is obese (BMI over 30), while more than 50 percent of the Dutch population wants to lose weight. ${ }^{4}$ Again, these are strong indications of the wide prevalence of self-control problems.

If time-inconsistent preferences, including willpower problems, procrastination and a strong present-bias, are the main reason why people make choices that do not maximize their (self-defined) long term welfare, it is unlikely that providing information will change behavior. In fact, evidence in the retirement savings domain indicates that while information may affect intention, it

2 A member of a Christmas Club saves throughout the year - often at a zero interest rate without the possibility to withdraw money from the savings account until Christmas. The purpose is to make sure that sufficient money is available in December to buy Christmas presents. 3 Poterba et al. (2003) argue that the tendency of elderly people to oversave could result from rational behavior with a bequest motive; see also Caplin and Schotter (2008) and Merton (2006). Another explanation is that markets lack financial instruments for life cycle planning for the elderly, such as reverse mortgages.

4 Source: LISS-panel (www.lissdata.nl). 
hardly affects behavior. Choi et al, 2002 study the reponse to financial education. They find that 100 percent plans to enroll in their employer's pension plan, but a mere $14 \%$ lives up to that resolution.

\section{MOTIVATIONS FOR INTERVENTIONS}

Key motivations for policy interventions with the explicit aim to affect individuals' behavior are paternalism and externalities. ${ }^{5}$ An important difference between the paternalistic policies in the current setting - 'libertarian paternalism' - and traditional paternalistic policies is that libertarian paternalism aims at helping individuals to act according to their own normative preferences. An axiom underlying the motivation for this type of intervention is that revealed preferences ("how much I actually save") and normative preferences ("how much I think I should save") are distinct concepts.

As early as 1956 Strotz identified potential self-control issues in intertemporal choice behavior and suggested precommitment as a possible solution (Strotz 1956). In a model that allows for a distinction between revealed and normative preferences, Thaler and Shefrin (1981) describe an internal principal-agent problem between a planner and a doer. The planner has a long time horizon and acts according to conventional economic theory, whereas the doer lives for the moment. Ashraf et al. (2005) show that Smith in his Theory of Moral Sentiments argues that much of human behavior is under the influence of the "passions" which are moderated by an internal "voice of reason", an "impartial spectator". Smith's impartial spectator is similar to the planner in Thaler and Shefrin's model of self-control. Herrnstein et al. (1993) assume the existence of multiple selves and use the term "negative internalities" to describe the effect of the behavior of the present doer on the future selves of the individual. Neuroeconomics provides support for the planner-doer model. FMRI (Functional Magnetic Resonance Imaging) scans show that different and conflicting - parts of the brain kick into action depending on the time frame. Short-term gratification is the domain of the limbic system, the impulsive part of the brain, whereas the neocortex - the part of the brain in charge of planning - wins on matters involving a long-term horizon (see, for example, Ainslie and Monterosso 2004).

A fundamental problem is whether and how an individual's own normative preferences can be identified. Dalton and Ghosal (2010) conclude that in theory normative preferences can be identified from an individual's choices

5 Although the motivations - paternalism, externalities - for policy interventions directed at protecting individuals and at affecting individual behavior are analytically different, many regulations serve both purposes. The obligation to wear a helmet helps not only avoiding social cost related to motor drivers accidents, but also avoiding regret by those who underestimate the negative effects and/or the chances of having an accident and the induced emotional suffering by others (Camerer et al. 2003). 
in selected restricted choice settings; see also Bernheim and Rangel (2009). Beshears et al. (2010) argue that actual choices reveal both normative preferences and decision-making biases. For example, when an employee takes five years to enroll in a pension plan this is suggestive of a legitimate (normative) preference for saving and a tendency to procrastinate. The 'asymptotic' choices are then more informative of normative preferences than short-run behavior. Other ways to measure normative preferences include forcing people to make any decision ("active choice"), simply asking people what they themselves think they should do, and relying on the opinion of impartial experts and trained consumers. While each of these methods to identify normative preferences has flaws, their combination is likely to provide the best possible answer to how normative preferences look like.

Taking normative preferences as a reference point for the evaluation of social welfare, policies can be designed that encourage individuals to act according to their own normative preferences.

\section{RETHINKING SAVINGS AND INVESTMENT POLICIES IN THE NETHERLANDS}

We discuss a number of recent policies in The Netherlands from a behavioral economics perspective.

\subsection{The 2007 Pension Act}

In the Netherlands a new Pension Act was adopted on January 1, 2007. The aim of the new law is to give more transparency and guarantees to employees, to give employees and retirees a legal right to information about their pension, and to provide a guarantee that the solvency of pension funds is adequate to pay out future pensions. Moreover, in light of the Act on Financial Services (WFD), pension plans have a "care-duty" (zorgplicht): they are to protect their clients' interests. The same applies to banks and insurance companies and financial advisors.

The new Pension Act distinguishes pension schemes according to the types of guarantees offered to employees. Plan participants should receive an annual leaflet with their pension claims. This leaflet has to be uniform among all pension plans. A national register is being set up with the aim of informing employees about all his pension rights accrued while participating in various plans during various jobs. In case of an individual defined contribution plan, the fund is responsible for creating a default portfolio. Should the employee opt out, then he has the right to invest his pension contributions within the limits set by the employer and the pension plan. The pension plan has to advise him in accordance with the know-your-customer $(k y c)$ principle, with portfolio risk falling as the retirement date draws closer. The kyc principle, as laid down in the law on the financial Services Act, implies that the par- 
ticipant's financial position, knowledge, expertise, goals and risk tolerance should all be taken into account. The pension plan has the duty to provide a yearly overview of results, comparing them to the results that would have been obtained if the employee had followed the advice.

Information and transparency for end users is an important component of the new pension act. While this represents an improvement over the previous state of affairs (no direct individual information for pension plan participants), the information is partial (only nominal wealth, no information on population probabilities like dying before retirement age). The mandatory default option in individual DC plans as well as the limits to investment possibilities for the DC participant in the new Pension Act are indications of a growing awareness among policymakers of the potential of standard options.

Many international experts regard the Dutch retirement system as one of the best, if not the best, worldwide. Yet, the reduced values of the portfolios backing pension fund liabilities triggered a policy debate about whether the risk of price movements in financial markets should be run by the company and its pension fund, or by individual employees. Several corporate pension funds intend to shift this risk toward the employees by a changeover from a defined benefit (DB) to a defined contribution (DC) pension scheme.

A defined contribution system has the potential of creating individually tailored pension plans and facilitating individual decision-making. As established in the previous sections, however, individual autonomy may not promote and indeed reduce individual welfare for many employees, due to behavioral biases and insufficient cognitive abilities; see Benartzi and Thaler (2002). Many individual DC pension funds in the US have expressed doubts about the quality of the investment choices made by their participants (Benartzi and Thaler 2001; Mitchell and Zeldes 1996). Thaler and Benartzi (2004) find that if left to choose, people save less than their optimal life cycle savings rate would predict. For the Netherlands, similar evidence on actual behavior is not available simply because the current system leaves very little choice to individuals. However, we have seen Dutch employees conform to the general pattern of financial illiteracy.

van Rooij et al. (2007) show that the vast majority of respondents is in favor of compulsory saving for retirement and of a defined benefit pension system. If offered a combined defined benefit/defined contribution system, the majority of the respondents would like to have a guaranteed pension income of 70 percent or more of their net labour income. If given investor autonomy, they are willing to change the composition of their retirement savings portfolio in response to their personal financial situation, general economic conditions, and expectations of financial markets. Respondents who have chosen a relatively safe portfolio (less stock, more bonds) appear to prefer the retirement income streams of the median investment portfolio to their own portfolio choice. The average respondent considers himself financially unso- 
phisticated, and is not eager to take control of retirement savings investment when offered the possibility to increase expertise. These findings strengthen the case for guidance. ${ }^{6}$

\subsection{The Life-course Arrangement}

One way to promote life cycle planning at the individual level is to create facilities to smooth income and leisure over time; see Bovenberg (2005). The life-course savings arrangement (levensloopregeling) introduced in 2006 in the Netherlands did originally have precisely this aim. Workers can save for when their personal circumstances make it attractive to have more leisure time. Tax facilities to promote life-course saving include tax deferral (omkeerregeling), subsidies for parents who use the life-course arrangement to stay at home with young children, and tax exemptions for subsidies by employers. When developing this facility, policymakers made no use of knowledge about behavioral incentives such as defaults. Thus, workers need to actively opt-out of the previous savings arrangement (spaarloon), and opt in in the life-course system.

The arrangement is both more expensive and less effective than was envisaged. However, a much more effective use could be made of defaults, labeling, and timing in the design and the implementation of the life-course scheme. As an example of using defaults, participation in the levensloopregeling could be set as the default choice rather than nonparticipation (which is the current default option for a large majority of employees). As an example of using labeling, "vacation allowance" could be relabeled into "savings allowance" or "contribution to life-course account". 7 Results in Kooreman et al. (2010) and Kooreman (2000) indicate that this change affects contributions to the lifecourse scheme, especially for households that are liquidity constrained. As an example of using timing of salary components, some salary components could be at a lower-than-monthly frequency, which is likely to be associated with a higher marginal propensity to save (see Kooreman et al. 2010).

\subsection{Financial Education}

As mentioned in Section 2, financial illiteracy is widespread, and financial education campaigns are popular. In the UK, the Financial Services Authority has launched a financial education campaign in 2006 (see www.fsa.gov).

6 A committee chaired by Frijns et al. (2010) recommends that pension funds offer and communicate real instead of nominal pension benefits, in order to prevent confusion (money illusion) for pension plan participants.

7 Vacation allowance - roughly 8 percent of annual net income - is paid in May. As of 2007, some employers have changed to paying vacation allowance as a monthly supplement to regular income. 
The US Treasury has launched its National Strategy for Financial Literacy in Autumn 2006. In November 2006, the Dutch Ministry of Finance established CentIQ, which aims to help financial consumers to become "well informed, educated, and able to confidently make well-considered financial decisions".

While carefully designed financial education could be effective in influencing intentions, it is unlikely to change behavior, given the evidence summarized in the previous sections. As we have seen, even with full information, many individuals make poor choices. Moreover, employees in the Netherlands are not motivated to increase their financial sophistication even if they are offered education at no cost (van Rooij et al. 2007). Given that new technologies have created a wider array of financial products to choose from, and deregulation policies have shifted more responsibilities and risk towards the individual, this can be interpreted as another manifestation of choice paralysis. Robert C. Merton argues that new technology and deregulation have

left households with the responsibility for making important and technically complex micro financial decisions involving risks ... ... that they had not had to make in the past, are not trained to make in the present, and are unlikely to execute efficiently in the future, even with attempts at education (Merton 2003).

In a world in which choice and risk are shifted to individuals, the traditional policy focus is on making markets work (hence the establishment of antitrust authorities and market conduct watchdogs) and on ensuring that individuals are well-informed (hence the programs for educating financial consumers, the new rules for transparency with regard to the quality of services and products). However, as Merton suggests, institutions - public and/or private should develop products that simplify decision-making for individuals. Information and financial illiteracy appear not to be the main issues, but rather the abundance of choice, temptation for immediate reward, few opportunities to learn from mistakes, and third party marketing that benefits from consumer irrationality (Beshears et al. 2010).

\subsection{The Possibly Detrimental Effects of More Competition in Financial Markets}

In the theory of product differentiation the basic task of firms is to bundle product characteristics into products that consumers can appreciate and choose from. It also allows for branding and brand loyalty and thus makes microeconomic theory more in line with what we see in the real world. However, as Laibson and Gabaix (2006) show, competition may increase consumer confusion and facilitate extracting rents from unsophisticated consumers. In 
Gabaix and Laibson's model, sophisticated consumers are subsidized in equilibrium by unsophisticated consumers.

To the extent that financial education has a role to play in planning for retirement saving, it is therefore important that the education is provided by impartial actors.

\subsection{Commitment Mechanisms}

Many citizens in the Netherlands (including civil servants) have limited or no freedom to make financial provisions for retirement. Others (including freelancers) are completely free in this respect. Policymakers should also offer commitment mechanisms to help them save enough for retirement in view of the evidence of undersaving.

Thaler and Benartzi (2004) report the results of the implementation of SMarT, a prescriptive program for retirement savings. Their goal was to ascertain whether implementing a commitment strategy for non-compulsory retirement savings would encourage workers to save more. The program consists of four elements. First, employees could commit to a savings plan where the sign-up date would lay far ahead of the actual start-up date. The purpose of the delay was to overcome the hyperbolic discounting problem. Second, workers committed to saving more after each nominal pay rise. Third, contributions would rise slowly until a maximum savings rate was reached. Finally, workers could opt out any time, but not lower their savings rate. Thaler and Benartzi find that the plan was extremely popular with participants, whose savings rate on average increased gradually from 3.5 to 13.6 percent. Similar commitment mechanisms can be straightforwardly applied in the Netherlands.

\section{RETHINKING HEALTH POLICIES IN THE NETHERLANDS}

\subsection{Limited Consumer Sovereignty}

If there is any domain of choice in which consumer sovereignty is severely limited, it is in healthcare. One obvious example is the case of emergencies, when consumer is often physically and/or mentally unable to make a decision of any kind. The same is true for mentally disabled persons and for young children. In life-threatening and other unsettling situations, decisions on healthcare are dictated by external factors, such as the location of a traffic accident and the decisions of third-party representatives. Although individuals could in principle choose in advance what they prefer if several contingencies materialize, optimal choices are difficult or impossible to make even for 
individuals who otherwise act in a fully rational manner. In these cases strong paternalism is both desirable and unavoidable. ${ }^{8}$

Secondly, even in a non-emergency situation, making appropriate decisions in health requires knowledge that takes health specialists many years of training to acquire. This asymmetry in information between principles (consumers) and agents (doctors) renders the former vulnerable (see Dulleck and Kerschbamer 2006). Moreover, a negative health shock of a given type is often a once-in-a-lifetime event, and therefore offers little opportunity for learning.

A number of studies (including Craik and Salthouse 2000), have shown that - apart from dementia and other illnesses - cognitive abilities (strongly) decrease in age after the age of 50. Agarwal et al. (2009) find evidence that financial mistakes follow a U-shape over the life cycle, with cost-minimization occurring around age 53. About half of the population between ages 80 and 89 either has dementia or a medical diagnosis of "cognitive impairment without dementia". The older population is thus even more vulnerable with respect to healthcare and other choices than are other groups in society.

The insights of Glaeser (2006) discussed in previous sections also have policy implications for healthcare markets. Given the asymmetry in information between consumers and providers that is inherent in healthcare, more competition and more alternatives are likely to increase consumer confusion.

\subsection{Minimizing Informational Failures}

Suboptimal choices partly result from informational failures and misperceptions of risks. Either there is ignorance or suppression (underestimation), or risks are exaggerated (hypochondria). For example, public perception of the risk of lung cancer for a lifetime smoker is about 0.45 , whereas actual risk is estimated to be about 0.10; see Khwaja et al. (2006), and Kip (2007). This type of misperception is partly due to the fact that government information on the detrimental effects of unhealthy behaviors is almost exclusively qualitative in nature. Government regulations in the Netherlands, for example, require that cigarette packs display the announcement "Roken is dodelijk" (smoking is lethal) in large bold print. It would be more informative to mention the approximate reduction in expected lifetime as a result of smoking one pack of cigarettes. Note that information could also discourage self-protective behavior if existing decision biases promote self-protection (smokers who stop because they overestimate the health risks of smoking; see Downs et al. 2009).

8 For preventive and elective care, healthcare demand elasticities with respect to prices (including travel time and costs) and quality are higher than for emergency care (see Ringel et al. 2002), suggesting more consumer sovereignty in former areas of healthcare. 
Since prevention can be a highly cost-effective intervention, many countries and insurers around the world encourage individuals to participate in certain types of preventive care. In the Netherlands, the government provides several preventive healthcare interventions free of charge to certain groups in the population. These include flu shots (population aged 65+, every year), cervical cancer tests (women 30-60 years old, every 5 years), and breast cancer tests ("mammograms"; women aged 50+, every 2 years). Public information on these preventive healthcare interventions is generally characterized by a similar lack of quantitative information. ${ }^{9}$ A more advanced way to disseminate risk information are websites that provides a personalized estimate of an individual's health risk as a function of basic demographic, health condition, and health-related behavior. An example is www.yourdiseaserisk.com.

Similar to other future investments, there are many reasons why people may not participate in these programs. While for some people non-participation is likely to be rational, many individuals who should rationally participate actually do not. Forward-looking individuals with a sufficiently low discount rate will rationally choose to participate in these programs. Those with a particularly high discount rate and those with an excellent general health status will rationally choose not to participate. However, myopia, cognitive biases and lack of information or understanding about the costs and benefits of these programs may lead others to choose, irrationally, not to participate.

Other policies to minimize informational failures include nutrition education (in schools and elsewhere) and improved nutrition labeling. Regulations in the Netherlands do not require nutrition labels to be in languages other than Dutch. However, as health risks are particularly prevalent in ethnic minorities with limited knowledge of Dutch, it might be helpful if nutrition labels contain information in a number of minority languages as well; see Variyam and Cawley (2006). However, in the study by Downs et al. (2009) calory information does not affect calory intake. De Ridder and de Wit (2007) finds that "light" labels could even increase calory intake, and thus work counterproductively. Glaeser (2006) argues that information that does not affect behavior merely imposes a psychological "tax" on consumers and should thus be avoided. Thus, while providing more information seems to be a noncontroversial policy recommendation, the evidence on its effectiveness is mixed. A similar conclusion holds for the effectiveness of food logo's; see Grunert and Wills (2007) and Health Council (2008). In any case, behavioral evi-

9 An exception is the website on mammograms (www.borstfoto.nl). The site also mentions that the screening has a large chance of a Type I error (test outcome is "negative" for a person who actually has the disease) and a Type II error (test outcome is "positive" for a person who actually does not have the disease). Thus, if the test turns out positive, a person is likely to be concerned, but this will be followed by relief in 6 out of 10 cases. This information is obviously highly relevant for deciding whether or not to take the test. 
dence underscores the importance of certification of information by impartial actors.

We briefly discuss three specific examples of how behavioral insights might be used more effectively in healthcare policies.

\subsection{Organ Donations}

Contrary to many other countries, organ donation laws and regulations in The Netherlands are based on the principle of "informed consent": individuals are assumed to be unwilling to donate organs after death, unless they have explicitly indicated otherwise. Recent studies suggest that organ donation rates are likely to increase if the system is changed into "presumed consent": a person is assumed to be willing to donate organs, unless he or she explicitly indicated otherwise (see, for example, Johnson and Goldstein 2003, and Abadie and Gay 2006). Where this meets with ethical objections, a useful alternative would be mandatory active choice. Government forms could contain a question "Do you wish to be an organ donor?" and require citizens to tick a box YES or NO, or Don't Know" (which would count as a NO). If tax forms cannot be submitted electronically unless one of the boxes is ticked similar to boxes that need to be ticked when booking an airline ticket - this would result in a significant increase in organ donors, without people being guided into an unwanted silent choice.

\subsection{Commitment Device for Attending a Health Club}

The evidence reported in DellaVigna and Malmendier (2006) and Charness and Gneezy (2009) shows that many members of health clubs sincerely intend to visit their club with a certain frequency, but fail to act accordingly. A possible self-enforcement mechanism looks as follows.

The consumer signs a contract with his/her health club in which he/she agrees to visit the health club (say) once a week. The contract also specifies that the consumer will be fined (say 200 percent of the price per visit) for each week skipped. He/she agrees that fines will be automatically and immediately charged from his/her bank account. As a reward for signing this contract, the first visit(s) will be free of charge. People attend less than they intended because they underestimate the (non-monetary) costs of the weekly visits to the health club. As the fine increases the costs of not going to the health club, individuals who lack willpower will be induced to go.

The scheme will be appealing to sophisticated hyperbolic discounters, who are aware of their tendency to behave inconsistently. The naive hyperbolic discounters will claim that they do not need the fine clause in their contract, but will be tempted to agree because of the free first visit(s). Another possibility is to attempt to educate naive hyperbolic discounters so that they will 
become sophisticated hyperbolic discounters, by confronting them with inconsistent behavior in the past.

In case the proposed incentive system generates positive net revenues, these can be used for some general (but not individual) health purpose.

\subsection{Setting Healthy Defaults}

Menu design in restaurants (for example by setting a vegetarian dish as the plat $d u$ jour) and the order of food display in cafetarias are other inexpensive ways to affect choice behavior. Adaptations in multi-story buildings can encourage visitors to take the stairs rather than the elevator; cf. Engbers (2007). As in other cases, such policies are paternalistic in the sense that the implicit price ratios (broadly defined) of various options are changed; at the same time these policies are libertarian since no option is excluded from the choice set.

\section{CONCLUSION}

The economics literature shows early traces of behavioral economics with the contributions by Smith (multiple selves), Samuelson (time preferences), Stigler (imperfect information), and Simon (bounded rationality). Building on these seminal contributions and psychological research, the field of behavioral economics has created more precise knowledge on how actual behavior deviates from full rationality. Recent theoretical contributions have formalized the distinction between revealed and normative preferences, aiming to develop a welfare theoretic basis for libertarian paternalism.

Behavorial insights help designing better policies that are less intrusive, less expensive, and more effective than many existing policies. Policies with more choice and more competition as basic principles can be counterproductive as a means to improve consumer welfare since they can create choice paralysis and consumer confusion. Issues like defaults and framing cannot be avoided, and therefore it is better to try to use them thoughtfully.

As with any government intervention, policy initiatives based soft-paternalism should be preceded by an analysis of costs and benefits and on a design that recognizes consumer heterogeneity. Preferably, full implementation should be preceded by small-scale field experiments to assess effectiveness. These experiments will contribute to a better understanding of the policy implications of behavioral economics.

Acknowledgment The authors thank Alwin Oerlemans, Rick van der Ploeg, Jan Potters, Marno Verbeek, Gerard de Vries, Joel van der Weele, and two anonymous referees for helpful comments on earlier versions of this paper. Netspar provided financial support. 
Open Access This article is distributed under the terms of the Creative Commons Attribution Noncommercial License which permits any noncommercial use, distribution, and reproduction in any medium, provided the original author(s) and source are credited.

\section{REFERENCES}

Abadie, A. and S. Gay (2006), 'The impact of presumed consent legislation on cadaveric organ donation: a cross-country study', Journal of Health Economics, vol. 25, pp. 599-620.

Agarwal, S., J.C. Driscoll, X. Gabaix and D. Laibson (2009), 'The age of reason: financial decisions over the life cycle and implications for regulation', Brookings Papers on Economic Activity.

Ainslie, G. and J. Monterosso (2004), 'A marketplace in the brain?', Science, vol. 306, nr. 5695, pp. 421-423.

Ashraf, N., C. Camerer and G. Loewenstein (2005), 'Adam Smith, behavioral economist,' The Journal of Economic Perspectives.

Benartzi, S. and R.H. Thaler (2001), 'Naive diversification strategies in retirement saving plans', American Economic Review, vol. 91(1), pp. 79-98.

Benartzi, S. and R.H. Thaler (2004), 'Save more tomorrow: using behavioral economics to increase employee saving', Journal of Political Economy, vol. 112, pp. S164-S187.

Bernheim, D. (1998), 'Financial illiteracy, education, and retirement saving,' in Living with Defined Contribution Plans, Pension Research Council, the Wharton School, University of Pennsylvania.

Bernheim, D. and A. Rangel (2009) 'Beyond revealed preference: choice-theoretic foundations for behavioral welfare economics', Quarterly Journal of Economics, 124, pp. 51-104.

Bernstein (1996), Against the gods: the remarkable story of risk, Wiley.

Beshears, J., J.J. Choi, D. Laibson and B.C. Madrian (2006), Simplification and saving, NBER Working Paper \#12659.

Beshears, J., J.J. Choi, D. Laibson and B.C. Madrian (2010), 'How are preferences revealed?', Journal of Public Economics, forthcoming.

Bovenberg, A.L. (2005), 'Balancing work and family life during the life course', De Economist, 153(4), 399-423.

Camerer, C. (2006), Behavioral economics, in Blundell, R., W. Newey and T. Persson (eds.), Advances in economics and econometrics: theory and applications, 9th World Congress of the Econometric Society, vol. 2.

Camerer, C., S. Issacharoff, G. Loewenstein, T. O’Donoghue and M. Rabin (2003), 'Regulation for conservatives: behavioral economics and the case of 'asymmetric paternalism", University of Pennsylvania Law Review, vol. 151, pp. 1211-1254.

Caplin, A. and A. Schotter, (eds.) (2008), The foundations of positive and normative economics - a handbook, Oxford University Press.

Charness, G. and U. Gneezy (2009), 'Incentives to exercise', Econometrica, 77, May, 2009, pp. 909-931.

Choi, J.J., D. Laibson, B. Madrian and A. Metrick (2005), 'Optimal defaults and active decisions', NBER Working Paper \# 11074.

Choi, J.J., D. Laibson and B.C. Madrian (2005), \$100 Bills on the sidewalk: suboptimal Saving in 401(K) Plans, NBER Working Paper \#11554. 
Craik, F.I.M. and T.A. Salthouse, (eds.) (2000), Handbook of aging and cognition, 2nd edition, Hillsdale, N.J.: Lawrence Erlbaum Associates.

Cronquist, H. and R. Thaler (2004), Design choices in privatized social-security systems: Learning from the Swedish Experience, American Economic Association Papers and Proceedings, vol. 94, pp. 424-428.

Dalton, P. and S. Ghosal (2010), Behavioral decisions and welfare, Working paper, Tilburg University.

DellaVigna, S. and U. Malmendier (2006), 'Paying not to go to the gym', American Economic Review, vol. 96, pp. 694-719.

DellaVigna, S. (2009), 'Psychology and economics: evidence from the field.' Journal of Economic Literature, 47(2), 315-372.

De Ridder, D. and J. de Wit (2007), 'Back to the future: what good are health goals in the presence of immediate interests?', Psychology and Health, vol. 22, pp. 513-516.

Downs, S., G. Loewenstein and Wisdom (2009), Strategies for promoting healthier food choices, American Economic Review Papers \& Proceedings 2009, vol. 99, pp. 159-164.

Dulleck, U. and R. Kerschbamer (2006), 'On doctors, mechanics, and computer specialists: the economics of credence Goods', Journal of Economic Literature, vol. 44, pp. 5-42.

Engbers, L.H. (2007), FoodSteps: The effects of a worksite environmental intervention on cardiovascular risk indicators, $\mathrm{PhD}$ thesis, Free University, Amsterdam.

Fehr, E. and J.-R. Tyran (2001), 'Does money illusion matter?', American Economic Review, vol. 91, pp. 1239-1261.

Frijns, J.M.G., J.A. Nijssen and L.J.R. Scholtens (2010), Pensioen: “ Onzekere zekerheid”, Commissie Beleggingsbeleid en Risicobeheer.

Glaeser, E. (2006), Paternalism and psychology, The University of Chicago Law Review, vol. 73, pp. $133-156$.

Grunert, K.G. and J.M. Wills (2007), 'A review of European research on consumer response to nutrition information on food labels', Journal of Public Health, vol. 15(5), pp. 384-399.

Health Council of the Netherlands (2008), Healthy nutrition: a closer look at logos, Health Council of the Netherlands, publication no. 2008/22E.

Herrnstein, R. G., Loewenstein, D., Prelec, and W., Vaughan, Jr. (1993), 'Utility maximization and melioration: internalities in individual choice', Journal of Behavioral Decision-making, vol. 6, pp. 149-185.

Hogarth, J.M., M. Hilgert and S. Beverly (2003), 'Houshold financial management: the connection between knowledge and behavior', Federal Reserve Bulletin, vol. 89, pp. 309-322.

Iyengar, S.S. and M.R. Lepper (2000), When choice is demotivating: can one desire too much of a good thing? Journal of Personality and Social Psychology, vol.79, pp. 995-1006.

Johnson, E.J. and D. Goldstein (2003), 'Do defaults save lives?', Science, vol. 302, pp. 1338-1339.

Johnson, E.J., J. Hershey, J. Meszaros and H. Kunreuther (1993), 'Framing, probability distortions and insurance decisions', Journal of Risk and Uncertainty, vol. 7, pp. 35-51.

Kahneman, D. and A. Tversky (1984), 'Choices, values and frames', American Psychologist, Vol. 39, pp. 341-350.

Khwaja, A., D. Silverman and F. Sloan (2006), 'Are smokers misinformed? Evidence from subjective beliefs about mortality and health', Working Paper.

Kip Viscusi, W. (2007), 'Regulation of health, safety, and environmental risks,' in A. Mitchell Polinsky and Steven Shavell, Handbook of law and economics, vol. 2. Amsterdam: Elsevier, NorthHolland. 
Kooreman, P., R.M. Faber and H.H. Hofmans (2004), 'Charity donations and the Euro introduction: some quasi-experimental evidence on money illusion', Journal of Money, Credit, and Banking, vol. 36 (2004), pp. 1121-1124.

Kooreman, P. (2000), 'The labeling effect of a child benefit system', American Economic Review, vol. 90(3), pp. 571-583.

Kooreman, P., H.M. Prast, N. vellekoop and B. Melenberg (2010), Labeling, frequency, and default effects in an employee savings scheme, Working Paper.

Laibson, D. (1997), 'Golden eggs and hyperbolic discounting', Quarterly Journal of Economics, vol. CXII, pp. 443-477.

Laibson, D. and X. Gabaix (2006), 'Shrouded attributes, consumer myopia, and information suppression in competitive markets', Quarterly Journal of Economics, vol. 2, pp. 505-540.

Levin, I.P., J. Schreiber, G.J. Gaeth ad M. Lauriola (2002), 'A tale of two pizzas: building up from a basic product versus scaling down from a fully loaded product', Marketing Letters, Vol. 13, pp. 335-344.

Lusardi, A. and O.S. Mitchell (2005), 'Financial literacy and planning: implications for retirement wellbeing', DNB Working Paper, vol. 78.

Merton, R.C. (2003), Future possibilities in finance theory and finance practice, Harvard Business School working paper, No. 01-030, 2000.

Merton, R.C. (2006), The future of personal finance, keynote address, conference on the future of life-cycle saving and investing, Boston University School of Management, Boston, October 26, 2006.

Miles, D. (2005), 'Incentives information and efficiency in the UK mortgage market', Economic Journal, vol. 115, pp. C82-C98.

Mitchell, O. and S. Zeldes (1996), 'Social security privatization: a structure for analysis', American Economic Review, vol. 86, pp. 363-367.

Poterba, J.M., S.F. Venti and Wise, D.A. (2003), Utility evaluation of risk in retirement saving account, NBER Working Paper, vol. \#9892.

Ringel, J.S., S.D. Hosek, B.A. Vollaard, S. Mahnovski (2002), The elasticity of demand for healthcare; a review of the literature and its application to the military health system, RAND Corporation.

Samuelson, P.A. (1937), 'A note on measurement of utility', The Review of Economic Studies, vol. 4, pp. $155-161$.

Schwartz, B. (2005), The paradox of Choice; why more is less, Harper Perennial.

Shafir, E., P. Diamond and A. Tversky (1997), 'Money illusion', Quarterly Journal of Economics, vol. 112 , pp. 341-374.

Simon (1957), Models of men; social and rational, Oxford University Press.

Stigler, J. (1961), 'The economics of information', Journal of Political Economy, vol.

Strotz, R.H. (1956), 'Myopia and inconsistency in dynamic utility maximization', The Review of Economic Studies, vol. 23, pp. 165-180.

Thaler, R.H. and Shefrin (1981), An economic theory of self control, Journal of Political Economy, 89, pp. 392-406.

Thaler, R.H. and S. Benartzi (2004), 'Save more tomorrow: using behavioral economics to increase employee saving', Journal Political Economy, vol. 112, pp. S164-S187.

van Rooij, M.C.J., C.J. Kool and H.M. Prast (2004), 'Risk-return preferences in the pension domain: are people able to choose?', Journal of Public Economics, vol. 91, pp. 701-722. 
Variyam, J.N. and J. Cawley (2006), 'Nutrition labeling and obesity', NBER Working Paper \# 11956.

Weinstein, M. (2005), 'Spending health care dollars wisely: can cost-effectiveness analysis help?', 2004 Herbert Lourie Memorial Lecture on Health Policy. 